\title{
EU COORDINATION OF NATIONAL SOCIAL SECURITY IN MULTIPLE CROSS BORDER SITUATIONS
}

\section{Jan CREMERS*}

\begin{abstract}
The coordination of the national social security is one of the crucial fields of cooperation between EU Member States. The coordination is based on the principle of application of one legislation at a time in cases of employment being executed in one or more than one Member State. Persons moving within the EU are thus subject to the social security scheme of only one Member State. The rules aim to guarantee equal treatment and non discrimination by the application of the lex loci laboris-principle. In 2004 the European legislator concluded modernised social security coordination rules (Regulation EC 883/2004) in order to simplify the current rules. The Implementing Regulation (Regulation EC 987/2009) was concluded in April 2009. The new rules came into effect from $1^{\text {st }}$ May 2010.

In this contribution the author explores the (possible) complications related to the new rules in situations with multiple cross border work activities. The paper consists of an overview of the applicable rules, of the basic changes and of pending questions. At the end a set of recommendations is formulated meant to contribute to the necessary tailor-made solutions.
\end{abstract}

Keywords: Free Movement, Migration, Social Security, EU Labour Market

\section{ÇOKLU SINIR ÖTESİ DURUMLARDA ULUSAL SOSYAL GÜVENLİĞİN AB KOORDINASYONU \\ $\ddot{O}_{z e t}$}

Ulusal sosyal güvenliğin koordine edilmesi AB üye ülkeleri arasindaki önemli işbirliği konularından biridir. Koordinasyon, istihdamın bir veya birden fazla üye ülkede gerçekleşmesi durumunda "bir seferde bir mevzuatın uygulanması" ilkesine dayanmaktadır. Böylece, AB içerisinde dolaşan bireyler sadece bir üye ülkenin sosyal güvenlik şemasina tabidir. Kurallar, işyeri kanunu prensibinin (lex loci laboris-principle) uygulanmasiyla eşit muamele ve ayrımcllık yapmamayl garanti altına almayı amaçlamaktadır. 2004 yllında Avrupalı parlamenterler mevcut

*Drs., Amsterdam Institute for Advanced Labour Studies, University of Amsterdam, e-mail: cremers@uva.nl 
kuralları basitleştirmek için modernize edilmiş sosyal güvenlik koordinasyon kurallarını (Regulation EC 883/2004) tamamlamıştır. Uygulama tüzüğ̈̈ (Regulation EC 987/2009) Nisan 2009'da tamamlanmıștır. Yeni kurallar 1 Mayıs 2010 tarihi itibariyle yürürlüğe girmiştir.

Bu katkısı ile yazar, çoklu sinır ötesi iş aktiviteleri ile ilgili durumlarda ortaya çıkabilecek yeni kurallara ilişkin (olası) karmaşıklıkları incelemektedir. Çalışma, yürürlükteki kralların, temel değişikliklerin ve bekleyen soruların genel bir değerlendirmesinden oluşmaktadır. Sonuç olarak, gerekli özel çözümlere katkıda bulunması amaçlanarak formüle edilmiş bir dizi tavsiye verilmektedir.

Anahtar Kelimeler: Serbest Dolaşım, Göç, Sosyal Güvenlik, AB Işsgücü Piyasası

\section{Introduction}

The coordination of the national social security is one of the crucial fields of cooperation between EU Member States related to the free movement principles. It has been a pillar of the European Community legislation from the start (Council of the EEC, 1958). The coordination as such is based on the principle of application of one legislation at a time in cases of employment being executed in one or more than one Member State. Persons moving within the EU are thus subject to the social security scheme of only one Member State. The 1957 Rome Treaty establishing the European Economic Community contained several provisions to ensure free movement of workers (Treaty of Rome, 1957, Articles 48- 51). Free movement of workers means in particular that workers who are nationals of one Member State have the right to go to another Member State to seek employment and to work there. The coordination rules aim to guarantee equal treatment and non discrimination. Workers have the right to settle with their families in their new host country and have to be treated equally as national workers in that host country. Although the form and content of the social security provisions belong to the competences of every individual Member State, the coordination of the different systems in cross border situations has been subject to a dynamic process of legislation and modification. Regulation no 3 of the Council of the European Economic Community that ruled the social security of migrant workers since its adoption in 1958 has been modified 14 times. Its successor, Regulation 1408/71, has been modified 39 times.

In 2004 the European legislator concluded modernised social security coordination rules (EC 883/2004, hereafter also called the basic Regulation) in order to simplify the current rules. The idea was also to limit the number of specific rules for different categories of professional activities. Regulation 883/2004 would come into force after the settlement of implementing legislation. The European Parliament reached an agreement with the Council of Ministers during the Czech presidency in early 2009 on the EC proposals for an Implementing Regulation. The 
European Parliament accepted the outcome of the negotiations with an overwhelming majority during a plenary meeting of the European Parliament in April 2009 (Regulation 987/2009).

Shortly before the final conclusion of the implementing legislation some questions rose related to the application of the new rules. Especially the application in case of multiple cross border activities of a structural kind in several Member States, like in the international transport sector or the European river navigation, asked for further explanation. After the consultation of some of the main stakeholders the EP decided to contact the EC services in order to clarify these questions. The Commission services underlined the necessity to examine the questions and discussed the item in the Administrative Commission for the Coordination of Social Security Systems. ${ }^{1}$

Both Parliament and the EC realised that it would be necessary to continue with the assessment of the impact of the new rules on specific types of workers' mobility with a strong cross border component. Any problems with the interpretation of the new rules for certain economic activities will ask for further cooperation between Members States. In the basic Regulation the need to promote cooperation as a key objective of the coordination rules is foreseen in article 72 .

This contribution EU Coordination of national social security in multiple cross border situations explores the differences between the 'old' and the 'new' regime. Regulation 1408/71 provides for many exceptions to its main rule on the legislation applicable - lex loci laboris. Regulation 883/2004 removed several derogation rules for special groups that were unnecessarily complicating the coordination system. The legislator aimed further simplification and modernisation of the coordination rules, but also wanted to address the unfair competition in the context of crossborder employment and to establish a dominant role for the Member State where a significant part of the activities is performed in the case of employment activities in two or more Member States. Therefore, Regulation 883/2004, no longer includes a specific exemption for flying and travelling personnel in international transport.

The article consists of an theoretical overview of the rules, of the basic changes and of pending questions. The question is raised whether the change under Regulation 883/2004 and its implementing Regulation 987/2009 has any unintended side-effects that can hinder the free movement of persons engaged as employees of undertakings that operate international transport services for

\footnotetext{
${ }^{1}$ The Administrative Commission for the Coordination of Social Security Systems has been created according to article 71-72 of the basic Regulation (883/2004). One of the tasks is to make 'any relevant proposals to the Commission of the European Communities concerning the coordination of social security schemes, with a view to improving and modernising the Community acquis by drafting subsequent Regulations or by means of other instruments provided for by the Treaty' (article 72.f).
} 
passengers or goods by rail, road, air or inland waterways. ${ }^{2}$ The focus was on the impact that the new rules would have for persons whose work pattern or activity implies a strong cross border dimension or component with activities in more than one other EU Member State. In the new application a key role is given to the 'substantial part of the activity`. At the end a set of recommendations is formulated that is meant to contribute to the necessary tailor-made solutions.

\section{The Legislative Frame - General Rules and Relevant Changes}

\subsection{Legislative Background}

Council Regulation (EEC) No 1408/71 of 14 June 1971 on the application of social security schemes to employed persons, to self-employed persons and to members of their families moving within the Community has been amended and updated on numerous occasions in order to take into account not only developments at Community level, including judgments of the Court of Justice as a result of permanent questioning of the scope and content of the coordination rules by national courts, but also changes in legislation at national level. ${ }^{3}$ Such factors have made the Community coordination rules complex and lengthy. Replacing these rules, while modernizing and simplifying, was necessary in order to contribute to an improvement of the standard of living and conditions of employment of EU citizens that make use of their right of free movement.

Therefore, a thorough revision of the rules was formulated and as a result Regulation 883/2004 was adopted in 2004. With the adoption of Regulation $883 / 2004$ it was decided that Regulation (EEC) No 1408/71 would remain in force and continue to have legal effect for the purposes of certain Community acts and agreements to which the Community is a party, in order to secure legal certainty. In the spring of 2009 the European Parliament and the Council of Ministers agreed on the proposed implementing legislation related to the complete renewal of the rules, as formulated in Regulation 883/2004. The resulting Regulation of the EP and the Council (987/2009) defined for all the parties involved (insured persons and members of their family, employers, social security institutions and the competent authorities of the Member States) the procedures for implementing the rules set out in the basic regulation.

\footnotetext{
${ }^{2}$ Special features like the specific situation of frontier workers or the position of posted workers are not treated as these would go far beyond the scope of this exploration. For the functioning of the posting rules in theory and practice reference can be made to a recent book by J. Cremers (2011). In Search of Cheap Labour in Europe, i-books, http://www.i-books.n1/

${ }^{3}$ Several authors have reviewed the jurisprudence of the European Court of Justice. As this is not the core item of this contribution we refer to for instance Christensen, A. \& Malmstedt, M. (2000). Lex Loci Laboris versus Lex Loci Domicilii - an Inquiry into the Normative Foundations of European Social Security Law. European Journal of Social Security, 2/1, 69-111.
} 


\subsection{Basic Principles}

In the frame of this contribution it is not necessary to give a detailed overview of all the formulated general coordination rules. These rules that were formulated as part of the modernisation of the rules with the main objective of a simplification for citizens have been documented with the publication of the legislative acts and were treated in extension by other authors (Pernot, 2004, Verschueren, 2004, Martinsen 2007, Eichenhofer, 2009).

It is, however, useful to summarise the basic principles of this coordination:

- application of the lex loci laboris, which means, as a general rule, that the legislation is applicable of the Member State in which the person pursues his/her activity as an employed or self-employed person,

- the determination of the legislation applicable and the responsible competent authority,

- the definition of a broad range of legislative matters concerning different branches of social security,

- the possibility to export benefits and to aggregate insurance periods,

- the coordination and systematic calculation of benefits.

The modifications had one additional aim: the limitation of the number of specific rules for different categories of insured persons and/or professional activities. This last objective could have serious consequences for insured persons being subject to the legislation of several Members States.

\subsection{The Coordination of Social Security in Theory}

EU citizens that exercise the right of free movement of persons are subject to the social security scheme of only one single Member State. As a general rule the legislation of the Member State in which the involved person pursues his/her activity as an employer or self-employed person is determined as the applicable legislation. In the coordination framework as formulated, derogation from the general rules is made possible in specific situations that justify other criteria of applicability.

In the past, the rules led to several controversies that most often concerned the line between social security and social assistance, the possible extension to other groups, the principle of the exportability and which, and how, social benefits had to be coordinated (Martinsen, 2007). In this context we concentrate on general rules and derogations that are related and relevant to situations for persons working in two or more other Member States. This paragraph ends with an overview (A) of unchanged or slightly changed fundamental rules and provisions. We also provide 
an overview (B) of different categories of cross border work. However, it has to be stressed that the rest of the article will concentrate on persons normally employed in the territory of two or more other Member States (the last category listed in Overview B).

In these overviews we abstract from the differences between self-employed persons and direct employed workers, because these differences are not relevant for the reasoning in this article.

The relevant changes will be explored in the next paragraph.

\section{Overview A. Basic rules in the Regulations}

\begin{tabular}{|c|c|c|c|}
\hline Item & $1408 / 71$ & $883 / 2004$ & 987/2009 \\
\hline $\begin{array}{l}\text { Single MS } \\
\text { legislation }\end{array}$ & $\begin{array}{l}13.1 \\
\text { Persons to whom this } \\
\text { Regulation applies shall be } \\
\text { subject to the legislation of a } \\
\text { single Member State only. }\end{array}$ & $\begin{array}{l}11.1 \\
\text { Persons to whom } \\
\text { this Regulation } \\
\text { applies shall be } \\
\text { subject to the } \\
\text { legislation of a } \\
\text { single Member } \\
\text { State only. }\end{array}$ & $\begin{array}{l}6.1 \\
\text { where there is a difference of views } \\
\text { between the institutions or } \\
\text { authorities of two or more Member } \\
\text { States concerning the determination } \\
\text { of the applicable legislation, the } \\
\text { person concerned shall be made } \\
\text { provisionally subject to the } \\
\text { legislation of one of those Member } \\
\text { States, the order of priority being } \\
\text { determined as follows: }\end{array}$ \\
\hline $\begin{array}{l}\text { 'Lex loci } \\
\text { laboris' }\end{array}$ & $\begin{array}{l}\text { 13.2.a en b } \\
\text { a) a person employed in the } \\
\text { territory of one Member State } \\
\text { shall be subject to the } \\
\text { legislation of that State even } \\
\text { if he resides in the territory of } \\
\text { another Member State or if } \\
\text { the registered office or place } \\
\text { of business of the undertaking } \\
\text { or individual employing him } \\
\text { is situated in the territory of } \\
\text { another Member State; } \\
\text { b) a person who is self- } \\
\text { employed in the territory of } \\
\text { one Member State shall be } \\
\text { subjected to the legislation of } \\
\text { that State even if he resides in } \\
\text { the territory of another MS }\end{array}$ & $\begin{array}{l}\text { 11.3.a } \\
\text { a person pursuing } \\
\text { an activity as an } \\
\text { employed or self- } \\
\text { employed person } \\
\text { in a Member State } \\
\text { shall be subject to } \\
\text { the legislation of } \\
\text { that Member State; }\end{array}$ & $\begin{array}{l}6.1 \text { (continued) } \\
\text { a) the legislation of the Member } \\
\text { State where the person actually } \\
\text { pursues his employment or self- } \\
\text { employment, if the employment or } \\
\text { self-employment is pursued in only } \\
\text { one Member State; } \\
\text { b) the legislation of the Member } \\
\text { State of residence where the person } \\
\text { concerned performs part of his } \\
\text { activity/activities or where the } \\
\text { person is not employed or self- } \\
\text { employed; } \\
\text { c) the legislation of the Member } \\
\text { State the application of which was } \\
\text { first requested where the person } \\
\text { pursues an activity or activities in } \\
\text { two or more Member States. }\end{array}$ \\
\hline
\end{tabular}




\section{Overview B. Multiple cross border work}

\begin{tabular}{|c|c|c|c|}
\hline $\begin{array}{l}\text { Employed } \\
\text { person in } \\
\text { two or } \\
\text { more } \\
\text { Member } \\
\text { States }\end{array}$ & $\begin{array}{l}14.2 \\
\text { 2. A person normally employed } \\
\text { in the territory of two or more } \\
\text { Member States shall be subject } \\
\text { to the legislation determined as } \\
\text { follows: } \\
\text { (a) A person who is a member of } \\
\text { the traveling or flying personnel } \\
\text { of an undertaking which, for hire } \\
\text { or reward or on its own account, } \\
\text { operates international transport } \\
\text { services for passengers or goods } \\
\text { by rail, road, air or inland } \\
\text { waterway and has its registered } \\
\text { office or place of business in the } \\
\text { territory of a Member } \\
\text { State shall be subject to the } \\
\text { legislation of the latter State, } \\
\text { with the following restrictions: } \\
\text { (i) where the said undertaking } \\
\text { has a branch or permanent } \\
\text { representation in the territory of } \\
\text { a Member State other than that } \\
\text { in which it has its registered } \\
\text { office or place of business, a } \\
\text { person employed by such branch } \\
\text { or permanent representation } \\
\text { shall be subject to the legislation } \\
\text { of the Member State in whose } \\
\text { territory such branch or } \\
\text { permanent representation is } \\
\text { situated; } \\
\text { (ii) where a person is employed } \\
\text { principally in the territory of the } \\
\text { Member State in which he } \\
\text { resides, he shall be subject to the } \\
\text { legislation of that State, even if } \\
\text { the undertaking which employs } \\
\text { him has no registered office or } \\
\text { place of business or branch or } \\
\text { permanent representation in that } \\
\text { territory. } \\
\text { (b) A person other than that } \\
\text { referred to in (a) shall be } \\
\text { subject: } \\
\text { (i) to the legislation of the } \\
\text { Member State in whose territory }\end{array}$ & $\begin{array}{l}\text { 13.1, } 13.3 \text { and } 13.5 \\
\text { 1. A person who } \\
\text { normally pursues an } \\
\text { activity as an employed } \\
\text { person in two or more } \\
\text { Member States shall be } \\
\text { subject to: } \\
\text { (a) the legislation of the } \\
\text { Member State of } \\
\text { residence if he/she } \\
\text { pursues a substantial } \\
\text { part of his/her activity in } \\
\text { that Member State or if } \\
\text { he/she is employed by } \\
\text { various undertakings or } \\
\text { various employers } \\
\text { whose registered office } \\
\text { or place of business is in } \\
\text { different Member States, } \\
\text { or } \\
\text { (b) the legislation of the } \\
\text { Member State in which } \\
\text { the registered office or } \\
\text { place of business of the } \\
\text { undertaking or employer } \\
\text { employing him/her is } \\
\text { situated, if he/she does } \\
\text { not pursue a substantial } \\
\text { part of his/her activities } \\
\text { in the Member State of } \\
\text { residence. } \\
\text { 3. A person who } \\
\text { normally pursues an } \\
\text { activity as an employed } \\
\text { person and an activity as } \\
\text { a self-employed person } \\
\text { in different Member } \\
\text { States shall be subject to } \\
\text { the legislation of the } \\
\text { Member State in which } \\
\text { he/she pursues an } \\
\text { activity as an employed } \\
\text { person or, if he/she } \\
\text { pursues such an activity } \\
\text { in two or more Member } \\
\text { States, to the legislation } \\
\text { determined in } \\
\text { accordance with par.1. }\end{array}$ & 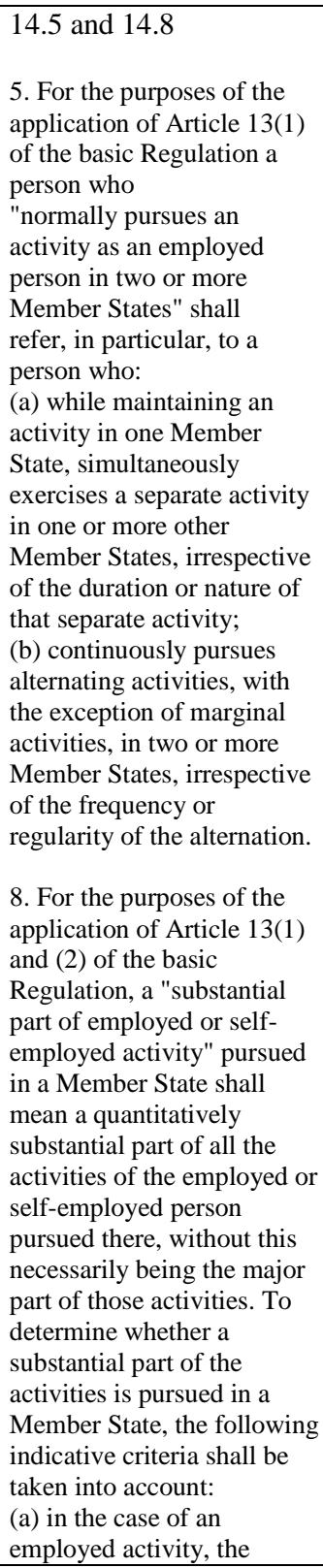 \\
\hline
\end{tabular}




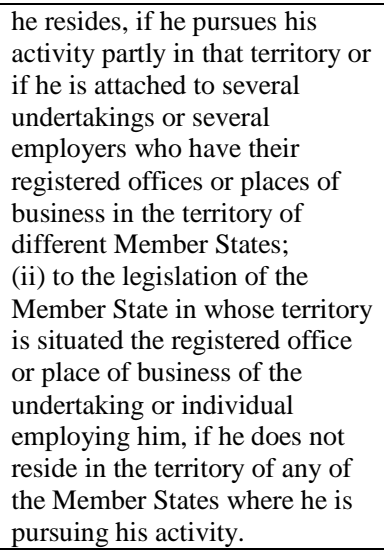

working time and/or the remuneration; and

(b) in the case of a selfemployed activity, the turnover, working time, number of services rendered and/or income.

In the framework of an overall assessment, a share of less than $25 \%$ in respect of the criteria mentioned above shall be an indicator that a substantial part of the activities is not being pursued in the relevant Member State.

\subsection{Relevant Changes in The Legislation}

We have indicated that the EC aimed to limit the number of specific rules for different categories of insured persons and/or professional activities. In the context of this paper the conclusion of the new Regulation 883/2004 brought one important change. Regulation 1408/71 provided in article 14.2a a specified exemption for persons normally employed in the territory of two or more Member States (see Overview B). Persons working for traveling or flying undertakings that operated international transport services for passengers or goods by rail, road, air or inland waterway and had the registered office or place of business in the territory of a Member State were subject to the legislation of the latter State.

This sectoral exemption is no longer present in the text of Regulation 883/2004. Instead the Regulation comes up with new rules as stated in a general article 13, Pursuit of activities in two or more Member States (comparable to the old 14.2b). The legislation of the Member State where the undertaking has the registered office is no longer the base; the new rules take the Member State of residence as the starting point (883/2004, article 13.1 in Overview B). Key element in the assessment is the question whether the person pursues a substantial part of his/her activity in that Member State.

The third part of article 13 specifies again the application of only one legislation for persons who normally pursues an activity as an employed person and an activity as a self-employed person in different Member States. They shall be subject to the legislation of the Member State in which they pursue an activity as an employed person or, if they pursue these activities in two or more Member States, to the legislation determined in accordance with article 13.1. 
The only sectoral activity with a general exemption that is maintained is the activity of employed or self-employed persons on board a vessel at sea (as specified in article 14b of Regulation 1408/71). However, compared to the "old" situation also this exemption is simplified in Regulation 883/2004 in a new article 11.4:

4. For the purposes of this Title, an activity as an employed or self-employed person normally pursued on board a vessel at sea flying the flag of a Member State shall be deemed to be an activity pursued in the said Member State. However, a person employed on board a vessel flying the flag of a Member State and remunerated for such activity by an undertaking or a person whose registered office or place of business is in another Member State shall be subject to the legislation of the latter Member State if he/she resides in that State. The undertaking or person paying the remuneration shall be considered as the employer for the purposes of the said legislation.

Given the fact that the sectoral exemption is deleted some industries and sectors will be confronted with a new situation. In the next paragraph we will treat the questions that are related to this new situation.

\section{Questions to be Solved}

\subsection{Determination of the Legislation Applicable}

We summarised the procedure related to the determination of the applicable legislation in a scheme that illustrates a possible step-by-step approach. The modification of the rules for coordination of national social security systems within the framework of free movement of persons has led to a debate with the legislator. The debate is related to the treatment of persons moving within the EU that pursue activities in two or more other Member States than the country of origin. The main change here is the introduction of the notion 'substantial'.

In this paragraph several questions are examined against the background of the provisions of Regulation 883/2004 and its implementing Regulation 987/2009:

a. In order to determine whether the legislation of the Member State of residence or the Member State of registered office has to be applied the wording 'substantial part of his/her activity' has to be defined.

b. In case of shifting and dynamic employment in multiple cross border situation a procedure is needed in order to guarantee transparent determination of the legislation applicable.

c. This procedure includes a decision making process on the legislation determined and on the duration of the decision made and the necessary flexibility in the system to be applied.

d. Finally, the question has to be answered if there are specific arguments that justify derogations from the general rule. If yes, it has to be decided which 
exceptions are acceptable and under which competence these exceptions can be formulated.

\subsection{What Is A 'Substantial' Part of His/Her Activity?}

The term 'substantial' did not figure in Regulation 1408/71. In practice, the application of article 14.2a was settled through definitions that varied from country to country. The decision whether the MS legislation of the registered office or place of business, or the legislation of the Member State of residence applied depended on national choices and differed accordingly.

Regulation 883/2004 introduced the term 'substantial part of his/her activity' in article 13.1 as the fundamental benchmark for the application of the legislation of the Member State of residence or the legislation of the Member State in which the registered office or place of business is situated. This distinction is decisive for the determination of the legislation. In article 14.8 of the implementing legislation this benchmark is further specified:

the following indicative criteria shall be taken into account:

(a) in the case of an employed activity, the working time and/or the remuneration; and

(b) in the case of a self-employed activity, the turnover, working time, number of services rendered and/or income.

In the framework of an overall assessment, a share of less than $25 \%$ in respect of the criteria mentioned above shall be an indicator that a substantial part of the activities is not being pursued in the relevant Member State.

Related to the subject of this study the percentage of (less than) $25 \%$ is a new threshold. Given the fact that persons who work in for instance the international road transport or the European river navigation will cross several borders of transit Member States, the question is legitimate whether the calculation of working hours in transit countries is relevant for the final distinction to be made between the Member State of residence and the Member State in which the registered office or place of business is situated. We will come back to this question. 
Scheme: Determination of the applicable legislation

1) Character of the transport activity

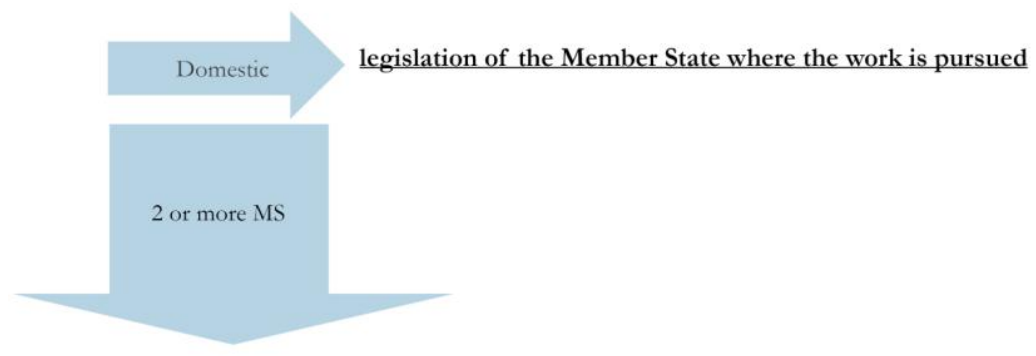

2) Relation between residence and registered office

a) MS of residence and MS of registered office are identical

Res $=$ Office $\quad$ legislation of the Member State of residence

b) MS of residence differs from the MS of registered office

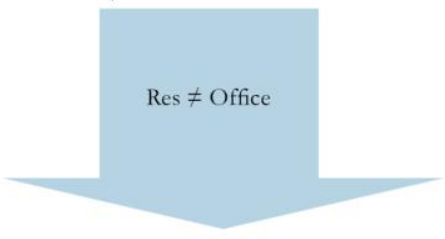

3) Dominant part of the activity

c) substantial part in MS of residence

Substantial legislation of the Member State of residence

d) no substantial part in the MS of residence

legislation of the Member State of registered office

Source: Jan Cremers (2010) Coordination of national social security in the EU - Rules applicable in multiple cross border situations, AIAS Working Paper 10-89, University of Amsterdam. 


\subsection{Which Procedure to Determine the Legislation Applicable?}

The determination of the applicable legislation is laid down in general rules (article 11 of Regulation 883/2004). The implementing legislation specifies in detail (in article 16.1 to 16.6) the procedure for the application of article 13. Fundamentally the starting point is: A person who pursues activities in two or more Member States shall inform the institution designated by the competent authority of the Member State of residence thereof.

For the person concerned the Member State of residence functions as the initiating authority that is responsible for the provisional determination of the applicable legislation. Where there is a difference of views between the institutions or competent authorities concerned, those bodies shall seek agreement in accordance with the conditions set out in Article 6 of the implementing Regulation.

\subsection{Decision Making, Duration and Flexibility}

The designated institution of the place of residence shall without delay determine the provisional legislation applicable to the person concerned. This provisional determination of the applicable legislation must become definitive within two months of the institutions designated by the competent authorities of the Member States concerned being informed.

However, where uncertainty requires contacts between the institutions or authorities of two or more Member States the legislation applicable to the person concerned is to be determined by common agreement. For the determination of the applicable legislation the concerned institutions shall take into account the situation projected for the following 12 calendar months (article 14.10). Article 11.1 (on the 'elements for determining the residence') of the implementing Regulation (987/2009) can be a possible reference where there is a difference of views between the institutions about the determination of the residence of a person to whom the basic Regulation applies. These institutions shall establish by common agreement the centre of interests of the person concerned, based on an overall assessment of all available information relating to relevant facts, which may include:

(a) the duration and continuity of presence on the territory of the Member States concerned;

(b) the person's situation, including:

(i) the nature and the specific characteristics of any activity pursued, in particular the place where such activity is habitually pursued, the stability of the activity, and the duration of any work contract;

(ii) his family status and family ties;

(iii) the exercise of any non-remunerated activity;

(iv) in the case of students, the source of their income; 
(v) his housing situation, in particular how permanent it is;

(vi) the Member State in which the person is deemed to reside for taxation purposes.

These elements might be combined with the indicative criteria as formulated in article 14.8 of the implementing Regulation.

\subsection{Derogations possible?}

We end this paragraph with an overview (C) of the modification of this part of the coordination principles. Regulation 883/2004 contains a general article with exceptions to the formulated provisions and procedures 'in the interest of certain persons or categories of persons' (article 16). The implementing Regulation provides (in article 18) a procedure for the application of exceptions, formulated as an individual case by case procedure.

\section{Overview C. Exceptions and conventions}

\begin{tabular}{|c|c|c|c|}
\hline Item & $1408 / 71$ & $883 / 2004$ & $987 / 2009$ \\
\hline $\begin{array}{l}\text { Exceptions } \\
\text { agreed } \\
\text { between MS }\end{array}$ & $\begin{array}{l}17 \\
\text { Two or more Member } \\
\text { States, the competent } \\
\text { authorities of these } \\
\text { States or the bodies } \\
\text { designated by these } \\
\text { authorities may by } \\
\text { common agreement } \\
\text { provide for exceptions to } \\
\text { the provisions of } \\
\text { Articles } 13 \text { to } 16 \text { in the } \\
\text { interest of certain } \\
\text { categories of persons or } \\
\text { of certain persons. }\end{array}$ & $\begin{array}{l}16.1 \\
1 . \text { Two or more } \\
\text { Member States, the } \\
\text { competent authorities } \\
\text { of these Member States } \\
\text { or the bodies } \\
\text { designated by these } \\
\text { authorities may by } \\
\text { common agreement } \\
\text { provide for exceptions } \\
\text { to Articles } 11 \text { to } 15 \text { in } \\
\text { the interest of certain } \\
\text { persons or categories } \\
\text { of persons. }\end{array}$ & $\begin{array}{l}18 \\
\text { A request by the employer or the } \\
\text { person concerned for exceptions to } \\
\text { Articles } 11 \text { to } 15 \text { of the basic } \\
\text { Regulation shall be submitted, } \\
\text { whenever possible in advance, to the } \\
\text { competent authority or the body } \\
\text { designated by the authority of the } \\
\text { Member State, whose legislation the } \\
\text { employee or person concerned } \\
\text { requests be applied. }\end{array}$ \\
\hline $\begin{array}{l}\text { Conventions } \\
\text { between MS }\end{array}$ & $\begin{array}{l}8.1 \\
1 . \text { Two or more Member } \\
\text { States may, as need } \\
\text { arises, conclude } \\
\text { conventions with each } \\
\text { other based on the } \\
\text { principles and in the } \\
\text { spirit of this Regulation. }\end{array}$ & $\begin{array}{l}8.2 \\
\text { 2. Two or more } \\
\text { Member States may, as } \\
\text { the need arises, } \\
\text { conclude conventions } \\
\text { with each other based } \\
\text { on the principles of } \\
\text { this Regulation and in } \\
\text { keeping with the spirit } \\
\text { thereof. }\end{array}$ & $\begin{array}{l}8.2 \\
\text { 2. Member States may conclude } \\
\text { between themselves, if necessary, } \\
\text { arrangements pertaining to the } \\
\text { application of the conventions } \\
\text { referred to in Article } 8(2) \text { of the } \\
\text { basic Regulation provided that these } \\
\text { arrangements do not adversely } \\
\text { affect the rights and obligations of } \\
\text { the persons concerned and are } \\
\text { included in Annex } 1 \text { to the } \\
\text { implementing Regulation. }\end{array}$ \\
\hline
\end{tabular}




\section{Practical Implications}

\subsection{Worries Expressed by Stakeholders}

The coordination rules aim to guarantee equal treatment and non discrimination. With the introduction of the Regulations 883/2004 and 987/2009 the applicable legislation for people working in the transport sector changed. One of the most important changes was that in principle the legislation of the Member State of residence applies. The legislation of the Member State where the employer has its registered office only applies if an employee does not perform a substantial part of his activities in his state of residence. The question has to be raised whether these changes can have any unintended side-effects that can hinder the free movement of persons engaged as employees of undertakings that operate international transport services for passengers or goods by rail, road, air or inland waterways.

In order to formulate an answer to this question the practical implications of the planned modification are to be considered. The author has consulted several stakeholders, social partner organisations at national and European level, experts in cross border items and national authorities.

The main worries formulated are the following:

-the 'old' system is easy and flexible, undertakings fear an increase of administrative burden,

-international transport services have work patterns that change permanently, projection of future work patterns is difficult as, due to a variety of clients, planning shifts from day to day,

-working time in the Member State of residence is not recorded and working time in transit countries and crossing borders are not registered separately. It is, therefore, complicated to calculate the proportion of the work pursued in the MS of residence,

-undertakings will be subject to different social security systems, with contributions paid to different authorities,

-employees of undertakings will be subject to different gross-net wage systems, -the definition of substantial part $(25 \%)$ is unworkable.

Some stakeholders have formulated possible advantages of the new rules:

-the risks of regime shopping are smaller, and the stimulus to work with letterbox companies is absent,

-distortion of competition might be therefore less,

-wages dispersions in the country of residence and in the territory of the applicable legislation will probably decrease. 


\subsection{Is There Any Evidence?}

Internal documents from employer organisations suggest that it might be hard for undertakings in the international transport sector to administrate how much of the work is performed by an employee in the state of residence. However, it is clear that there is only little empirical underpinning for the arguments expressed. Data that could give an answer to the question whether the new rules will lead to a substantial increase of administrative problems are lacking. The data provided by some stakeholders are difficult to verify. The provided numbers are often the total of foreign born employees working for the transport companies in a country. And strictly spoken only people working for an undertaking in a different country than where they live and who are performing a substantial part of their activities in their country of residence are affected. This reduces the number of the people affected in a substantial way. It is thus quite probable that only for a small number of workers in the international transport sector the applicable legislation will change. It is to be recommended that the national administrations work out an overview of the relevant figures.

Against this background the following remarks have to be made:

-The flexibility argument would be valid if the old registration system would stay upright. With the newly intended registration the determination of the legislation applicable and the provision of an attestation are feasible in a short period of time. In that respect the new rules could (more than) compensate the necessary administrative work.

-Changing work patterns should not lead to modifications if the structural dimension of the executed work remains of the same character. The organisations do have a strong point in this matter. If a person works for an undertaking that operates transport services for passengers or goods by rail, road, air or inland waterways the main argument has to be whether this work is of a domestic nature or of an international nature. If the second is the case the use of an attestation that will run for a longer period of validity, notwithstanding minor changes in that international transport, seems logically.

-In the implementing legislation a threshold (of at least 25\%) is introduced as being the decisive condition for the choice between the legislation of the Member State of residence and the Member State in which the registered office or place of business is situated. So far it is unclear how to calculate this percentage. The argument of some of the stakeholders that the working time in transport services for passengers or goods by rail, road, air or inland waterways is not recorded according to countries crossed is not so easy to refute. 


\subsection{Further Elaboration of the Procedure Needed?}

Concrete experience with the application of the new rules is still missing and it will probably take several years before some practical consequences for people working in the transport sector might be found. As a consequence it is too early to draw hard conclusions related to the applicable procedure. We have indicated that, according to the formulated rules, the institution of the Member State of residence has the lead at the beginning of the process. The provided Scheme of the determination of the applicable legislation illustrates the step-by-step procedure that has to be applied. During the interviews we could not find hard figures with regard to the number of people involved. Therefore, we don't know how many persons are involved once the first two steps have been taken (Step 1: distinction between domestic and international transport, Step 2: MS of residence and MS of registered office/place of business are identical or not).

With regard to these first two steps there are no substantial controversies.

In fact, the main worries can be all linked to the interpretation of article 14.8 of the implementing legislation (in our Scheme Step 3) and pinpoint the wording and definition of the 'substantial part of the activity', the duration of the attestation and the like. ${ }^{*}$

This could be a reason for a close examination of the different decisions related to that article.

The following elements have to be considered in that exercise:

-How to work out other criteria, next to the indicative criteria given, for cases of multiple cross border activities of a structural kind in several Member States?

-It has to be decided how heavily the percentage of $25 \%$ weighs in cases with multiple cross border activities.

-Is a sectoral calculation necessary, possible and workable that abstracts from daily and weekly working time in transit countries?

-Is it possible to work out a decisive ground for the real decision to be made (determination of the legislation: MS of residence or MS of registered office/place of business)?

-Is it possible to elaborate an attestation that is tailor-made for the sectors concerned and at the same time reliable?

\footnotetext{
* A complicated situation is not touched upon here; when the person does not pursue any activity in either MS of residence or MS of registered office/place of business, but in other Member States. Regulation cannot be build upon exceptionable circumstances and it seems to be wise in this situation to go back to the basic rule (territory where most work is pursued).
} 


\section{Possible Way Out - Some Final Considerations}

\subsection{How to Handle Specific Situations?}

So far, we have treated the issue of multiple cross border work from the legal perspective and we have listed some of the practical implications. Before we come to a concluding section we have to elaborate the theoretical possibilities for a wayout based on the legislation.

In the final text of Regulation 883/2004 it is said that specific situations that justify other criteria of applicability, can lead to derogation from the general rule. In the final text of the regulation and in the implementing legislation different roads for this derogation are mentioned:

\section{a) Modification of the Regulatory framework}

The modification and renewal of Regulation 1408/71 have gone a long way. With the conclusion of the implementing legislation the new rules can be made operational. However, the new rules provide procedures for further modification (in articles 72 and 75 of Regulation 883/2004). A key role is reserved for the Administrative Commission for the Coordination of Social Security Systems. Article 72.f of the basic Regulation states very clearly that the Administrative Commission can make any relevant proposals to the European Commission of the European Communities concerning the coordination of social security schemes, with a view to improving and modernizing the Community acquis.

In addition article 75.2 states that the Advisory Committee is empowered at the request of the Commission of the European Communities, the Administrative Commission or on its own initiative:

(a) to examine general questions or questions of principle and problems arising from the implementation of the Community provisions on the coordination of social security systems, especially regarding certain categories of persons;

(b) to formulate opinions on such matters for the Administrative Commission and proposals for any revisions of the said provisions.

Based on our analysis the conclusion can be drawn that it is too early to come up with new initiatives for revision related to the item treated in this article. The European Commission has proposed in 2010 an amendment of the rules that aims to cover employees employed by various employers. The condition of pursuing a 'substantial part' of the activity does not apply to the situation in which a person is working in two or more Member States for various undertakings or employers. According to the EC this is not in line with the intention when negotiated in 
Council, especially not for the situation in which the activity pursued in the Member State of residence is relatively small. ${ }^{4}$

\section{b) Joint instruction on the application}

In the basic Regulation the need to promote further cooperation between Members States is formulated as a key objective of the coordination rules. This cooperation is foreseen in article 72 as a whole. Specifically for particular questions it is said in article 72.c that the Administrative Commission:

c) foster and develop cooperation between Member States and their institutions in social security matters in order, inter alia, to take into account particular questions regarding certain categories of persons; facilitate realisation of actions of cross border cooperation activities in the area of the coordination of social security systems;

According to these articles the Administrative Commission can take the lead in this dispute.

c) Exemption based on common agreement between two or more Member States

The basic Regulation includes an article (Article 16.1) that provides for exceptions to the formulated rules:

1. Two or more Member States, the competent authorities of these Member States or the bodies designated by these authorities may by common agreement provide for exceptions to Articles 11 to 15 in the interest of certain persons or categories of persons.

The procedure for a request in this area is formulated in the implementing Regulation (article 18):

Procedure for the application of Article 16 of the basic Regulation

A request by the employer or the person concerned for exceptions to Articles 11 to 15 of the basic Regulation shall be submitted, whenever possible in advance, to the competent authority or the body designated by the authority of the Member State, whose legislation the employee or person concerned requests be applied.

Close reading of this article suggests that the exemption as formulated in article 16 of the basic regulation must be seen as an individual exception granted at

\footnotetext{
${ }^{4}$ The Proposal for a Regulation of the European Parliament and of the Council amending Regulation (EC) No 883/2004 on the coordination of social security systems and Regulation (EC) No 987/2009 laying down the procedure for implementing Regulation (EC) No 883/2004 is pending in the European Parliament
} 
national level with a bilateral or multilateral effect, not as a broader and general exemption at EU level of whole sectors of activity.

\subsection{Joint Policies and Case-By-Case Procedures}

In order to guarantee that employees and self-employed persons are benefiting from adequate statutory social security protection the cooperation between Member States is seen as a key element in the coordination principles. The problems with the interpretation of the new rules for certain economic activities ask for joint reflections and activities. The Administrative Commission has to work on further clarification and, if necessary, the possibility to facilitate the implementation of the new rules by formulating new and additional instructions for the weighing of criteria prevailing for these economic activities. Part of these instructions can be inspired by article 11 of the implementing regulation.

Given the crucial role of social partners in the fight against social dumping and distortion of competition these instructions have to be elaborated in close cooperation and consultation. As there is a need for a fair share of benefits and contributions between the Member States in the EU the author suggests also tabling means to counteract the abuse of letterbox companies in these consultations.

\subsection{Can There Be Reference to Other Legal Instruments?}

The main question raised in this debate is related to the exact nature of the difficulties in applying the new rules of legislation. Several of our respondents stressed the risks with the fall back position that is now present. If there is no substantial part of activity in the country of residence the legislation of the country where the office is registered applies. Reference was made to practices in the airline industry. There is a clear risk for regime-shopping at the expenses of the protection of the workers. How can the insurability be guaranteed and determined? What if this registered office is not more than a letterbox company?

According to the Commission services this situation can be tackled by Decision 2A of the Administrative Commission (see box).

\section{Decision A2 of the Administrative Commission}

4. The provisions of Article 12(1) of Regulation (EC) No 883/2004 shall not apply or shall cease to apply in particular:

(a) if the undertaking to which the worker has been posted places him at the disposal of another undertaking in the Member State in which it is situated;

(b) if the worker posted to a Member State is placed at the disposal of an undertaking situated in another Member State;

(c) if the worker is recruited in a Member State in order to be sent by an undertaking situated in a second Member State to an undertaking in a third Member State. 
With regard to the terms 'registered office' and 'working place' in case of persons with occupations as international travelling or flying personnel reference can be made to other regulations in the air and road transport.

For instance Regulation 1899/2006 defines the 'home base' for crew members. It is the location from where 'the crew member normally starts and ends a duty period'. If the 'operational base' and the 'home base' are identical and the person pursues or starts from there this could be a guiding principle for air transport.

A new Regulation in the road transport (entering into force 4 December 2011) conditions the entry into the sector and defines the 'establishment'. The aim of proper compliance with, and reliable monitoring of, the conditions governing admission to the occupation of road transport operator presupposes that undertakings have an effective and stable establishment.

REGULATION (EC) No 1071/2009 OF THE EUROPEAN PARLIAMENT AND OF THE

COUNCIL of 21 October 2009 establishing common rules concerning the conditions to be complied with to pursue the occupation of road transport operator

\section{Article 3}

Requirements for engagement in the occupation of road transport operator

1. Undertakings engaged in the occupation of road transport operator shall:

(a) have an effective and stable establishment in a Member State;

\section{Article 5}

Conditions relating to the requirement of establishment

In order to satisfy the requirement laid down in Article 3(1)(a), an undertaking shall, in the Member State concerned:

(a) have an establishment situated in that Member State with premises in which it keeps its core business documents, in particular its accounting documents, personnel management documents, documents containing data relating to driving time and rest and any other document to which the competent authority must have access in order to verify compliance with the conditions laid down in this Regulation. Member States may require that establishments on their territory also have other documents available at their premises at any time;

\subsection{Final Considerations}

A transparent and coherent interpretation of the new rules on the applicable legislation with respect to the coordination of the social security for people working in two or more Member States is of great interest to sectors in which multiple cross border activities are being performed, as for example the international transport sector. Mutual understanding of the Member States on the interpretation of these new rules and of the transitional provisions is a necessary condition to come to a consistent application of those rules. The specific features of travelling and flying personnel in international transport have lead to a debate about the impact of the new rules. 
This article explores the rules of the applicable legislation under Regulation $883 / 2004$ and the modifications that are formulated by the European legislator compared to the rules applicable under Regulation 1408/71 are treated. The changes relevant for persons pursuing work in the territory of two or more Member States are examined and some key questions are formulated. A first analysis of implications is provided and the key items to be solved are listed.

The author comes to the conclusion that there is no hard evidence that employees and self-employed persons will be confronted with serious risks if the Regulation is applied as envisaged. Undertakings will be confronted under the new rules with new procedures. However, there is no hard evidence for negative effects on competition. The worries formulated by several sectors can be tackled by the necessary improvements in the implementation phase. Regulation 883/2004 and its implementing Regulation provide enough flexibility to formulate tailor-made solutions.

Notwithstanding these remarks additional and joint work is needed. The procedures that lead to the determination of the applicable legislation have to be examined carefully. The so-called indicative criteria that lead to decisions regarding the determination of the applicable legislation are to be made operational in a transparent and consistent way. While it is obligatory, in the context of carrying an overall assessment, to take account of working time and/or remuneration, 883/04 and its implementing Regulation do not provide an exhaustive list and other criteria may also be taken into account.

When determining the "substantial part" of activity for persons employed in the international transport sector one can argue whether in the case of international transport workers, the calculation of working hours in transit countries (Member States other than the Member State of residence or Member State in which the employers' registered office or place of business is situated) are relevant for the determination of the legislation applicable. It looks more consistent to treat the working time spent in transit countries as not to the point for the fundamental choice between the Member State of residence and the Member State in which the registered office or place of business is situated. Otherwise the calculation that should underpin this fundamental choice is blurred by the irrelevant duration of the activity in one or more other Member States.

The design of a joint set of conditions, formulated in the same way as Decision A2 is necessary in this area. Two parts of the legislative frame were mentioned in this report. First the reference to 'the elements for determining the residence'; secondly the idea that the institutions concerned should take into account the situation projected for the following 12 calendar months. The last procedure can be seen as a solution to avoid a 'yo-yo effect. Other additional criteria have to be considered, partially referring to article 11 of the implementing Regulation: the 
centre of interests of the person based on an overall assessment and related to relevant facts as duration, continuity of presence, labour law, remuneration and taxation applicable.

The risks of distortion of competition and regime-shopping that were present under the old regime will probably decrease once the Member States of residence (of the employee concerned) work out the determination of the applicable legislation according to the new rules. In order to avoid a rigid procedure the recommendation is to use the projection stated in article 14.10 (related to the determination of the applicable legislation) as the basis for an attestation with a validity of a certain period, of for instance one year, that can be easily renewed and only has to be revised in case of structural changes in the work pattern. 


\section{References:}

The Council of the European Economic Community (1958). Regulation (EEC) No. 3 of 25 September 1958, O.J. No. 30 of 16 December 1958.

The Council of the European Communities (1971). Regulation (EC) No 1408/71 of 14 June 1971 on the application of social security schemes to employed persons, to selfemployed persons and to members of their families moving within the Community. Consolidated version as published 28.04.2006, Official Journal of the European Union.

Eichenhofer E (ed.) (2009), 50 Jahre nach ihrem Beginn - Neue Regeln für die Koordinierung sozialer Sicherheit, Beiträge zur Sozialpolitik und zum Sozialrecht (BSS), Bnd 38, Erich Schmidt, Berlin.

The European Parliament and the Council of the European Union (2004). Regulation (EC) No 883/2004 of the European Parliament and of the Council. Corrigendum as published 7.6.2004, Official Journal of the European Union.

The European Parliament and the Council of the European Union (2009). Regulation (EC) No 987/2009 of the European Parliament and of the Council of 16 September 2009 laying down the procedure for implementing Regulation (EC) No 883/2004 on the coordination of social security systems. Version as published 30.10.2009, Official Journal of the European Union.

Martinsen, D. S. (2007). 'The Social Policy Clash: EU Cross-Border Welfare, Union Citizenship and National Residence Clauses'. Paper EUSA, Montreal, Canada. Retrieved October 10, 2011 from http://aei.pitt.edu/7964/

Pernot, A. (2004). Le remplacement du règlement 1408/71 par le règlement 883/2004 relatif à la coordination des régimes de sécurité sociale, Revue Belge de sécurité sociale, Special Issue, $\mathrm{N}^{\circ} 4$, pp 653-660.

Treaty of Rome, 25 March 1957. http://ec.europa.eu/economy_finance/emu_history/ documents/treaties/rometreaty2.pdf.

Verschueren, H. (2004). Le nouveau règlement (CE) n 883/2004 une réplique, Revue Belge de Sécurité sociale, Special Issue, N4, pp. 677-682. 
